\title{
DEBATES
}

\section{O que as páginas dos partidos dizem sobre eles? Análise de redes das páginas oficiais dos partidos politicos brasileiros no Facebook}

\author{
What do party pages say about them? Network analysis of the \\ official pages of brazilian political parties on Facebook
}

\author{
Nilton Garcia Sainz \\ Raquel da Cunha Recuero
}

\section{Resumo}

O objetivo desta pesquisa é compreender os padrốes de conexóes existentes nas páginas dos partidos políticos brasileiros no Facebook. A partir de uma coleta de dados realizada pelo Netvizz e da opção "page like network", analisamos as redes com dois graus de profundidade, observando as conexóes das páginas do PSOL, PT, MDB, SDD, PSL e PL, partidos com maior representação na Câmara dos Deputados em 2019, de acordo com a classificação ideológica adotada. A partir disso, utilizando o método de Análise de Redes Sociais, analisamos as métricas do grau de entrada e da modularidade. Como principais resultados, observamos a existência de padróes de conexão entre as páginas dos partidos políticos. Nota-se que existem partidos fortemente conectados a atores políticos, instituiçóes, movimentos sociais e redes de militância, assim como partidos políticos que não possuem conexões com as instituições em sua rede.

\section{Palavras-chave}

Partidos Políticos; Sites de Redes Sociais; Análise de Redes; Comunicação Política; Facebook.

\begin{abstract}
Our research seeks to understand the patterns of connection of key Brazilian parties on Facebook. The data was collected through Netvizz and the option "page like network" with two degrees of depth and examined the connection network of PSOL, PT, MDB, SDD, PSL e PL, parties with the most representation, in the Chambers of Deputies. We used social network analysis to examine these networks through modularity and indegree. Our results show the existence of neighborhood patterns between pages of political parties. There are parties connected to institutions, political actors, social movements and militancy networks, as well, as those with no connections to institutions in their network.
\end{abstract}

\section{Keywords}

Political Parties; Social Networking Sites; Network Analysis; Political Communication; Facebook. 
28 | Nilton Garcia Sainz e Raquel da Cunha Recuero

\section{Introdução ${ }^{1}$}

Diante das transformações ocorridas no mundo da comunicação política nos últimos anos, percebe-se que atores políticos, cada vez mais, utilizam como ferramenta a internet. Ainda um fenômeno recente - a utilização de sites de redes sociais, que estão servindo para expor e publicar os perfis de atores políticos (RECUERO, 2009) - passou a fazer parte do cotidiano de quem utiliza sites de redes sociais. $\mathrm{Na}$ política atual, observa-se o uso dessas redes desde para campanhas eleitorais até na atuação de governos e instituições, que as utilizam para alcançar os cidadãos.

As eleições de 2018 no Brasil, apresentaram um alto consumo de comunicação online por parte dos atores envolvidos. Atualmente, o Brasil é o terceiro país com mais usuários (130 milhões) no site de rede social Facebook (BRASIL..., 2019). Com o objetivo de alcançar o maior número de eleitores, os partidos políticos brasileiros buscaram se adaptar a essa realidade. Dos 32 partidos políticos do Brasil, 31 possuem páginas no Facebook ${ }^{2}$ divulgadas em seus websites e que são consideradas oficiais pelas siglas partidárias.

Compreendendo que a atuação de um candidato ou partido político nas redes sociais não é algo que ocorre de maneira isolada (DOS SANTOS e TAVARES, 2016), pois os conteúdos alcançam e são compartilhados por diversos outros atores, a pesquisa investigou as páginas oficiais dos partidos políticos brasileiros no site de rede social Facebook. Com isso, o objetivo deste estudo é compreender os padróes de conexões existentes nas páginas dos partidos políticos, buscando, por meio dessa fonte de investigação, conhecer as características das instituiçôes partidárias no site de rede social. Diante disso, busca-se responder: quais características possuem as páginas que fazem conexão com os partidos políticos brasileiros no Facebook e o que elas dizem sobre esses partidos e seu caráter institucional na internet?

O estudo fez uso do método de Análise de Redes Sociais (ARS), coletando os dados por meio de uma ferramenta de crawler, que percorreu a rede e mapeou as ligaçôes entre os atores. Logo após, analisou-se a rede por meio do software Gephi. Através do método de ARS, foi possível realizar uma abordagem relacional dos partidos políticos e suas conexôes no Facebook, observando os laços que as páginas

\footnotetext{
${ }^{1}$ Agradecemos a equipe da Revista Debates e os pareceristas anônimos por suas sugestôes que ajudaram a qualificar o artigo.

${ }^{2}$ Apenas o Partido Trabalhista Cristáo (PTC) não possui página divulgada em seu website ou que podemos considerar oficial no Facebook.
} 
partidárias possuem, ou seja, as conexóes que se estabelecem na rede a partir da página partidária analisada.

$\mathrm{O}$ universo da pesquisa compreende os partidos com maior representação na Câmara dos Deputados no momento da posse em 2019 e selecionou os analisados de acordo com classificação ideológica, na intenção de capturar diferentes características dos partidos, e em relação aos diferentes tamanhos. Adotou-se a classificação dos partidos proposta por Bolognesi e Codato (2018), que utilizaram como base o estudo elaborado por Coppedge (1997), o que resultou na análise de seis partidos políticos. $\mathrm{Na}$ Tabela 1, a partir de dados coletados no $1^{\circ}$ semestre de 2019 , observamos os partidos analisados de acordo com a classificação ideológica, tamanhos de bancadas e informações gerais da página oficial no Facebook.

Tabela 1 - Partidos políticos analisados

\begin{tabular}{l|l|l|c|l|l}
\hline $\begin{array}{l}\text { Classificaçá } \\
\text { o }\end{array}$ & $\begin{array}{l}\text { Partido } \\
\text { número de }\end{array}$ & $\begin{array}{l}\text { Neputados } \\
\text { na câmara }\end{array}$ & Página Analisada & $\begin{array}{l}\text { Número } \\
\text { de } \\
\text { curtidas } \\
\text { na página } \\
\text { do } \\
\text { Facebook }\end{array}$ & $\begin{array}{l}\text { Frequência de } \\
\text { interaçáo na } \\
\text { página por hora }\end{array}$ \\
\hline Esquerda & PSOL & 10 & www.facebook.com/psol50 & 455.798 & 0.17 \\
\hline $\begin{array}{l}\text { Centro- } \\
\text { esquerda }\end{array}$ & PT & 54 & www.facebook.com/pt.brasil & 1.551 .794 & 0.60 \\
\hline Centro & MDB & 34 & www.facebook.com/MDBNacional15/ & 78.964 & 0.02 \\
\hline Personalista & SDD & 13 & www.facebook.com/solidariedadebr & 44.555 & 0.01 \\
\hline Direita & PSL & 51 & www.facebook.com/PartidoSocialLiberalBR/ & 207.738 & 0.09 \\
\hline $\begin{array}{l}\text { Confessional } \\
\text { Direita }\end{array}$ & PL & 33 & www.facebook.com/partidodarepublicanacional/ & 2.821 & 0.99 \\
\hline
\end{tabular}

Fonte: Elaboração própria.

As informações da Tabela 1 mostram que as páginas mais populares no Facebook estão concentradas no campo da esquerda. PT e PSOL possuem as páginas com maiores números de curtidas no site, chamando a atenção para o caso do PSOL, que mesmo sem ter grandes conquistas eleitorais, possui uma popularidade significante no site. A terceira posiçáo é ocupada pelo PSL, partido que teve um crescimento eleitoral importante em 2019 e elegeu o atual presidente da República.

\footnotetext{
3 Partido Socialismo e Liberdade (PSOL); Partido dos Trabalhadores (PT); Movimento Democrático Brasileiro (MDB); Solidariedade (SDD); Partido Social Liberal (PSL); Partido Liberal (PL), antigo Partido da República (PR), a sigla e o nome foram alterados em 2019, mas a página do partido continua "Partido da República - Nacional".
} 
$\mathrm{Na}$ sequência, estão o MDB, SDD e PL. As surpresas ficam por conta do MDB, que, apesar de sua história e importância institucional, não possui grande popularidade no Facebook. Já o PL surpreende por conta da sua alta frequência de interação na página.

Além desta introdução, que apresentou a investigação realizada, o artigo está organizado em cinco seçôes: as duas primeiras revisam parte da literatura sobre partidos políticos e internet, a terceira seção apresenta detalhadamente a metodologia que foi empregada na pesquisa, a quarta seção apresenta os resultados, articulando o que foi encontrado com a literatura que suporta a investigação, e, por fim, a quinta, que traz as consideraçôes, com uma reflexão final sobre o que foi encontrado a partir deste estudo.

\section{As primeiras impressões sobre internet e partidos politicos}

No final dos anos 90 e início dos anos 2000, surgiram os primeiros estudos que abordaram o uso da internet pelos partidos políticos. A literatura, na grande maioria de origem norte-americana, buscava entender as consequências que a internet traria para os sistemas políticos e as democracias contemporâneas.

Buscando uma maneira de compreender as mudanças que a internet provocaria na comunicação política e analisando as mudanças e o uso da internet pelas instituições partidárias, as investigações percebiam a necessidade de os partidos buscarem reengajamento e novas formas de comunicação com os eleitores (GIBSON, NIXON e WARD, 2003). Diante dos percalços e dificuldades da democracia representativa e dos partidos políticos, o uso da internet na política dividia-se em cenários otimistas e pessimistas. Inicialmente, diversas características positivas são identificadas no uso dos websites pelos partidos políticos. A web resultaria em um processo de comunicação mais imediato, dinâmico, aprofundado, interativo e diferente das mídias tradicionais (GIBSON e WARD, 2000; NORRIS, 2003.

Segundo Gibson e Ward (2000), através do uso da web, os partidos políticos poderiam buscar melhores resultados eleitorais com menores custos, sendo possível promover: a) informaçóes, alcançando rapidamente o público e divulgando políticas públicas e identidades do partido; b) campanhas, sendo um espaço para recrutar novos eleitores, principalmente através do espaço para informação gerado, amplo e que possibilita para aqueles que não possuem espaços nos veículos tradicionais um tipo de comunicação com os eleitores, além da característica multimídia e de alcance do eleitorado jovem; c) geração de recursos, por meio da interação e do alcance global, buscando apoios financeiros e recrutando novos membros; d) networking, 
construindo conexões internas e externas dos partidos, fortalecendo relações com instituições, imprensa, políticos eleitos e grupos de pressão, como sindicatos e movimentos sociais; e) participação, construindo um ambiente propício para a participação política por meio da informação e ampliação de canais interativos de comunicação com o partido, pelos quais é possível ter retornos sobre políticas, propostas e alcançar líderes partidários; além da possibilidade de debates, por meio de chats em tempo real (GIBSON e WARD, 2000; NORRIS, 2003; GIBSON, NIXON e WARD, 2003).

Os primeiros estudos tratavam com cautela a possibilidade de a internet promover um ambiente mais equalizado entre os partidos políticos. A principal discussão é sobre a capacidade de partidos menores se equipararem com os partidos maiores por meio do uso da internet e se de fato isso traria resultados nas eleiçóes (NORRIS, 2003; GIBSON, NIXON e WARD, 2003). Supostamente, um partido menor, que dispõe de menores recursos, pode obter um site e a utilização da internet, assim como um partido que está no governo, transformando o cenário que antes era de desaparecimento ou exclusão de partidos menores em mídias tradicionais (NORRIS, 2003). O uso da internet também afetaria os regimes autoritários, que teriam uma maior dificuldade no controle de fluxos de informações e atuação das oposiçóes (GIBSON, NIXON e WARD, 2003). No entanto, os estudos apontam para a inexistência de um consenso em relação à capacidade da internet de tornar a disputa eleitoral mais igualitária entre os partidos políticos. Dessa forma, imaginavase a possibilidade de reprodução do mundo offline, onde os que possuem maiores recursos terão maiores vantagens na construção de suas campanhas e atuações online (GIBSON, NIXON e WARD, 2003).

As pesquisas realizadas no início dos anos 2000 não trouxeram resultados otimistas. Nelas se verificou algumas tendências e resultados, como: a) o baixo número de acesso aos websites dos partidos políticos nos países da União Europeia e dos Estados Unidos; b) resultados que indicavam para indiferença na relação entre websites de partidos políticos e padrões de votação; c) uso dos websites partidários pelos mais jovens, o que resultou na esperança de que as transiçóes geracionais transformassem esse cenário; d) a maior utilização da internet pelas sedes centrais dos partidos e pelas principais lideranças, não descentralizando como era o esperado; e) apesar de os partidos considerarem benéfica a internet para a adesão de novos filiados, os dados não demonstram aumento nos números de recrutamentos (GIBSON, NIXON e WARD, 2003). Norris (2003), com uma visão aparentemente mais 
otimista sobre o uso da internet pelos partidos, também destaca a não existência de um ambiente para debates, como anteriormente havia sido imaginado. Porém, a autora relata que os websites de partidos e candidatos fortalecem a democracia representativa, ao passo que também tornam mais competitivo o jogo eleitoral para atores políticos com menores expressões eleitorais (NORRIS, 2003).

\section{Dos websites aos sites de redes sociais: como os partidos politicos brasileiros têm usado a internet?}

Seguindo a agenda de pesquisa sobre partidos políticos e internet, as primeiras investigações no Brasil também se voltaram a compreender o uso dos websites pelos partidos políticos (BRAGA, FRANÇA e NICOLÁS, 2009; RODRIGUES, BARROS e BERNARDES, 2014; BARROS, 2015; BRAGA, ROCHA e CARLOMAGNO, 2017).

Investigando a atuação dos partidos na web em 2008, o estudo de Braga, França e Nicolás (2009) contribui, empiricamente, para compreender o modo como os partidos políticos brasileiros estavam organizando suas estratégias de comunicação nos websites. Nessa oportunidade, dos 27 partidos políticos brasileiros, apenas um não fazia uso de um website, o que, segundo os autores, já demonstrava uma espécie de padronização e existência de um "subsistema partidário virtual". Os resultados da pesquisa apontam para a existência de déficits em relação às páginas de alguns partidos, que não disponibilizavam recursos importantes em seus websites - um exemplo é em relação às ferramentas de interatividade, que apresentam baixo aproveitamento (BRAGA, FRANÇA e NICOLÁS, 2009; RODRIGUES, BARROS e BERNARDES, 2014). O estudo indica para a não ocorrência da chamada "normalização", em que os padróes de atuação dos partidos na internet seriam o mesmo do mundo real. Segundo essa investigação, partidos menores estavam equiparados com os demais no uso da internet.

A contribuição de Rodrigues, Barros e Bernardes (2014) analisou as estratégias de comunicação de 32 partidos, seis a mais que a investigação anteriormente citada. Os autores identificaram padróes similares na comunicação das siglas em seus websites, nos quais os partidos "[...] dialogam com o eleitorado, como afirmam sua identidade institucional e também procuram atuar como mediadores entre a sociedade e as instituições governamentais do Poder Executivo" (RODRIGUES, BARROS e BERNARDES, 2014, p. 30), além de buscarem visibilidade para os partidos. A investigação identifica que 29 dos 32 partidos analisados buscam atingir públicos específicos, indo ao encontro de demandas e 
interesses de segmentos da sociedade, como mulheres e jovens, o que é explicado devido à quantidade de eleitores em tais segmentos (RODRIGUES, BARROS e BERNARDES, 2014; BARROS, 2015). O estudo identificou que 25 partidos políticos em 2014 utilizavam o Facebook, e mostrou um alto investimento em sites de redes sociais por parte dos partidos com maiores bancadas na Câmara dos Deputados na época (PMDB e PT) (RODRIGUES, BARROS e BERNARDES, 2014).

Por fim, a investigação de Braga, Rocha e Carlomagno (2017) comparou a atuação dos partidos políticos brasileiros e portugueses na internet. $O$ estudo observou que, principalmente no caso brasileiro, existem partidos que atuam pouco na internet, não sendo efetivos no uso das ferramentas online para buscar engajamento e ficando caracterizados por websites pouco diversificados, com pouca presença e atenção para as mídias sociais (BRAGA, ROCHA e CARLOMAGNO, 2017). Um dado interessante revelado pelos autores é a correlação entre tamanho de bancada e presença no Facebook, assim como o número de prefeituras e a presença no site de rede social (BRAGA, ROCHA e CARLOMAGNO, 2017), o que ajuda a explicar o fato dos partidos PMDB e PT possuírem esse destaque no Facebook.

\section{Metodologia aplicada à pesquisa}

Por meio da ARS, a pesquisa analisa as estruturas de interaçôes entre atores sociais, neste caso, as relaçóes de poder entre os partidos políticos e suas respectivas comunicações político-eleitorais, formadas a partir de conexôes no site de rede social (DOS SANTOS e TAVARES, 2016). A coleta de dados ocorreu através da página oficial dos partidos analisados no Facebook, por meio do aplicativo Netvizz ${ }^{4}$ e da opção "page like network", que realiza o crawling da página analisada, mapeando suas redes de conexôes. Utilizando essa opção do aplicativo, optou-se por usar o grau 2 de profundidade da rede, que possui uma maior capacidade de investigar as conexóes (ou o que chamamos de grau), coletando as páginas que se conectam a outras e as conexões entre essas páginas e dessas páginas.

Para analisar as redes, utilizamos duas métricas típicas da Análise de Redes Sociais: a modularidade, que é uma métrica de agrupamento e que mostra grupos a partir das conexóes (por exemplo, páginas que estáo em contado entre si tendem a aparecer no mesmo grupo), e grau de entrada, uma métrica de centralidade, pela qual é possível analisar quais páginas são mais centrais na rede. As métricas e os grafos

\footnotetext{
${ }^{4} \mathrm{O}$ Netvizz é um aplicativo que funciona como uma ferramenta de crawler.
} 
34 | Nilton Garcia Sainz e Raquel da Cunha Recuero

foram elaborados pelo software Gephi, nele foram calculados a modularidade e o grau de entrada das páginas.

As páginas no Facebook constituem-se em uma rede não simétrica porque é possível a uma página curtir outra e não receber a mesma conexão em retorno. Uma rede simétrica é aquela em que a conexão não é direcionada, ou seja, a conexão existe em ambos os sentidos (de A para B e de B para A). Por conta disso, o grau de entrada é uma métrica importante, pois mostra a centralidade dos nós (páginas) que mais receberam conexôes na rede. Assim, o conceito de "nó" serve para representar as páginas, e as arestas representam as ligaçôes (curtidas) que são realizadas pelas páginas na rede.

A métrica de modularidade serve para a identificação de módulos e aponta a tendência de um determinado nó aparecer em um desses grupos (RECUERO, 2014). É, assim, uma métrica de grupabilidade, ou seja, serve para a identificação de grupos e suas respectivas conexôes, apresentando, com base na centralidade do nó, a sua tendência a estar dentro de um determinado módulo de outros nós que também têm conexôes similares. Neste trabalho, os clusters são representados através de cores. Essa métrica é importante para indicar a vizinhança das páginas.

A métrica de grau de entrada (indegree) é uma medida de centralidade, ela aponta o número de ligaçôes (conexôes) que existem na rede para um determinado nó. Na Tabela 2, apresentamos os resultados obtidos com a análise de redes realizada, demonstrando os números achados em cada página investigada.

Tabela 2 - Modularidade e Grau médio de cada análise realizada

\begin{tabular}{c|c|c|c|c}
\hline Objeto analisado & Modularidade & Grau de entrada & $\mathbf{N}^{\circ}$ de nós & $\mathbf{N}^{\circ}$ de arestas \\
\hline PSOL & 0,441 & 186 & 2.535 & 24.267 \\
\hline PT & 0,488 & 370 & 4.120 & 45.627 \\
\hline MDB & 0,502 & 188 & 5.151 & 41.875 \\
\hline SDD & 0,521 & 69 & 1.344 & 10.296 \\
\hline PSL & 0,342 & 0 & 490 & 2.875 \\
\hline PL & 0,532 & 28 & 559 & 2.425
\end{tabular}

Fonte: Elaboração própria.

Observa-se na Tabela 1 que a rede que possui o maior número de páginas é do $\mathrm{MDB}$, com mais de 5 mil páginas, seguida pela rede do PT, que possui mais de 4 mil páginas. $\mathrm{O}$ número de arestas das redes do $\mathrm{MDB}$ e do $\mathrm{PT}$ são os mais altos, indicando uma maior inserção no ecossistema de páginas, uma maior popularidade dentro deste. É interessante o fato dos dois maiores partidos analisados, em termo de 
abrangência nacional e sucesso eleitoral na Nova República, serem os responsáveis por concentrar as maiores redes, o que pode ser atrelado à forte institucionalidade dos dois partidos e a atenção que esses investiram nas mídias sociais (RODRIGUES, BARROS e BERNARDES, 2014; BRAGA, ROCHA e CARLOMAGNO, 2017). O PSOL apresenta o terceiro maior número de páginas e ligações entre os analisados, seguido do SDD. Apesar de ter conquistado a presidência em 2018, o PSL não possui uma presença, em termos de conexóes, destacável no Facebook, o número de páginas que compõem sua rede é menor que do PL; no entanto, possui um número de arestas um pouco maior. $\mathrm{O}$ fato de o PSL não possuir uma rede com tamanho expressivo pode ser consequência do tamanho do partido até 2018, que, apesar de já fazer parte do cenário nacional há algum tempo, não havia obtido grandes conquistas eleitorais e ampla representação pelo país.

\section{Análise dos dados}

Os resultados da pesquisa serão apresentados seguindo a ordem das tabelas $1 \mathrm{e}$ 2. Dessa forma, seguiremos a seguinte ordem: PSOL, PT, MDB, SDD, PSL e, por fim, o PL. Antes de analisar cada partido, realizamos uma breve descrição das siglas com base em seus programas e diretrizes doutrinárias (SENADO FEDERAL, 2014).

O PSOL obteve seu registro no TSE no ano de 2005 e nasce com uma identidade ligada a diversas lutas e movimentos sociais. Em seu programa, o partido se coloca como uma alternativa socialista no país, reforçando sua atuação junto aos trabalhadores e minorias, além de buscar fortalecer movimentos sociais que representam a luta de diversos segmentos da sociedade (PSOL, 2014). Atualmente, o PSOL possui 10 deputados na Câmara, o que demonstra um crescimento em relação à última legislatura, quando havia conquistado cinco cadeiras. No Facebook, o partido é o segundo maior em relação a curtidas em sua página oficial, ficando atrás apenas do PT. No grafo (Figura 1), observamos a rede de páginas que estão conectadas à página do partido. 
Figura 1 - Rede da página oficial do PSOL no Facebook

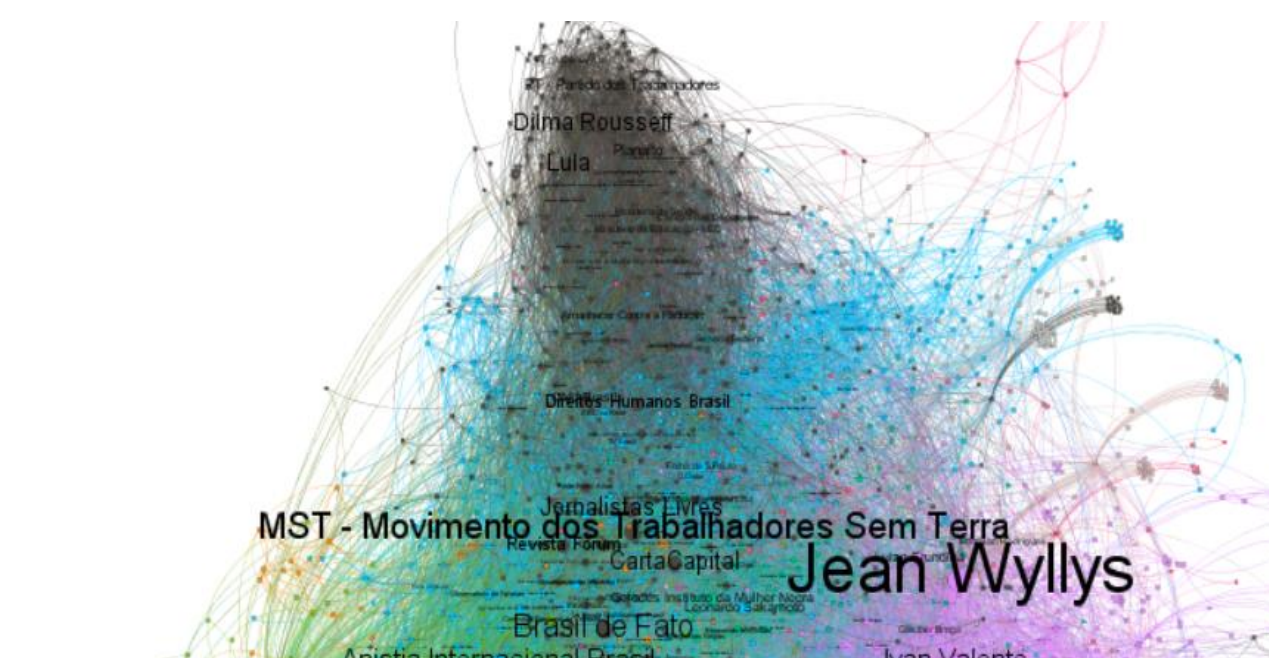

\section{Mídia Ninja- \\ mantive}

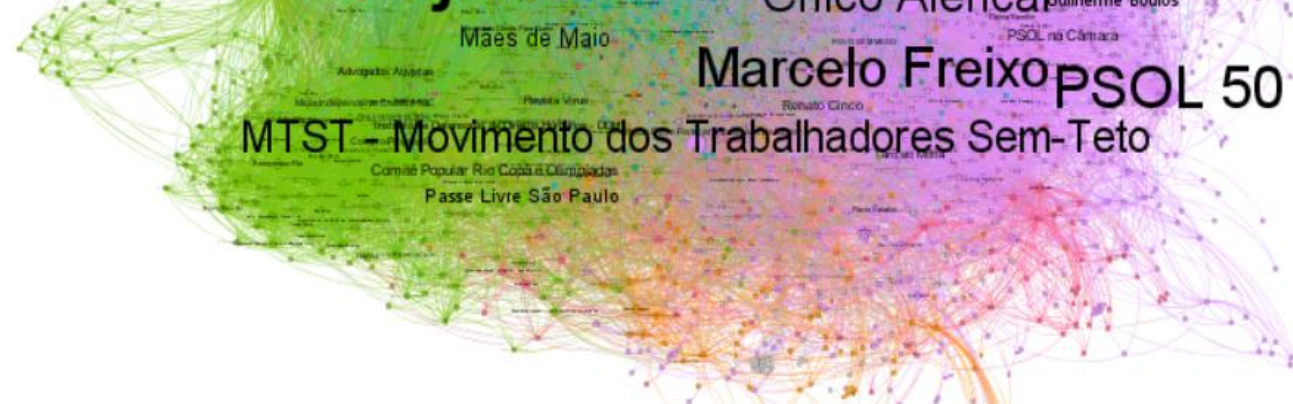

Nota: Os maiores nomes indicam uma maior centralidade (grau de entrada).

Fonte: Elaboração própria.

Iniciaremos a análise pelo cluster roxo, em que está presente a página do partido "PSOL 50". Nota-se, que o nó do partido assume uma expressão considerável dentro do cluster e da rede, sendo o segundo nó com maior grau de entrada no cluster roxo (ficando atrás da página de Jean Wyllys). Nesse mesmo sentido, percebese que esse cluster é formado por quadros do partido, como: "Marcelo Freixo", "Jean Wyllys", "Chico Alencar" e "Luciana Genro". O que aponta para proximidade entre as páginas dos principais quadros do partido com a página oficial da sigla. Também é possível encontrar movimentos sociais ligados ao partido, como: "Movimento dos Trabalhadores Sem-Teto" e "Povo Sem Medo", o que indica uma aproximação da página do partido com esses movimentos sociais. Seguindo para o cluster verde, é 
possível identificar que a página do PSOL no Facebook possui uma proximidade também com outros movimentos sociais, como "Passe Livre São Paulo", "Mães de Maio" e também veículos de imprensa contra-hegemônicos, como "Mídia Ninja" e "Mídia Independente Coletiva - MIC", que partilham engajamento em questóes sociais e políticas com o partido. Nesse sentido, observa-se conexões que refletem pontos do programa partidário do PSOL, o que reforça a identidade do partido com lutas sociais e indica o fortalecimento de redes internas e externas do partido na comunicação online (GIBSON e WARD, 2000).

No caso do cluster azul, percebe-se a presença do movimento social "Anistia Internacional Brasil" e também alguns outros veículos de imprensa, como "Agência Pública", "Folha de São Paulo" e "O Globo". É possível identificar que esse cluster fica centralizado no grafo, revelando ser o principal ponto de ligação entre os clusters da rede.

Por fim, o cluster preto tem perceptível, em sua extremidade, a presença de páginas ligadas ao PT. Nota-se a própria página institucional da sigla, além de seus principais quadros, como "Lula" e "Dilma". Também é possível observar nesse cluster a presença de algumas páginas institucionais, como "Planalto", "Senado Federal" e "Câmara dos Deputados", além das páginas dos ministérios. Isso demonstra que as redes das páginas desses partidos políticos estão bem próximas, indicando uma semelhante "vizinhança" entre as páginas, ou seja, parte das páginas que se conectam ao PSOL, no Facebook, também se conectam ao PT.

O PT surgiu na transição do bipartidarismo para o pluripartidarismo, sendo registrado oficialmente pelo TSE em 1980. Ainda sob o último governo militar, o PT apresentou-se como um partido de massas, comprometido com a consolidação democrática e com a luta pela independência política dos trabalhadores (PT, 2014). Para além do movimento dos trabalhadores, o PT buscou acolher outros diversos segmentos da sociedade que buscavam se inserir na política pós regime autoritário, assim, existindo uma forte representação de trabalhadores rurais, camponeses, funcionários públicos, estudantes, negros, índios, mulheres etc. (PT, 2014). Recentemente, o partido sofreu duras derrotas eleitorais, porém, permanece com a maior bancada na Câmara dos Deputados, com 54 cadeiras, 15 a menos que na última legislatura, quando assumiram 69 deputados federais. No grafo a seguir (Figura 2), apreciaremos a rede formada a partir da análise do PT no Facebook. 
Figura 2 - Rede da página oficial do PT no Facebook

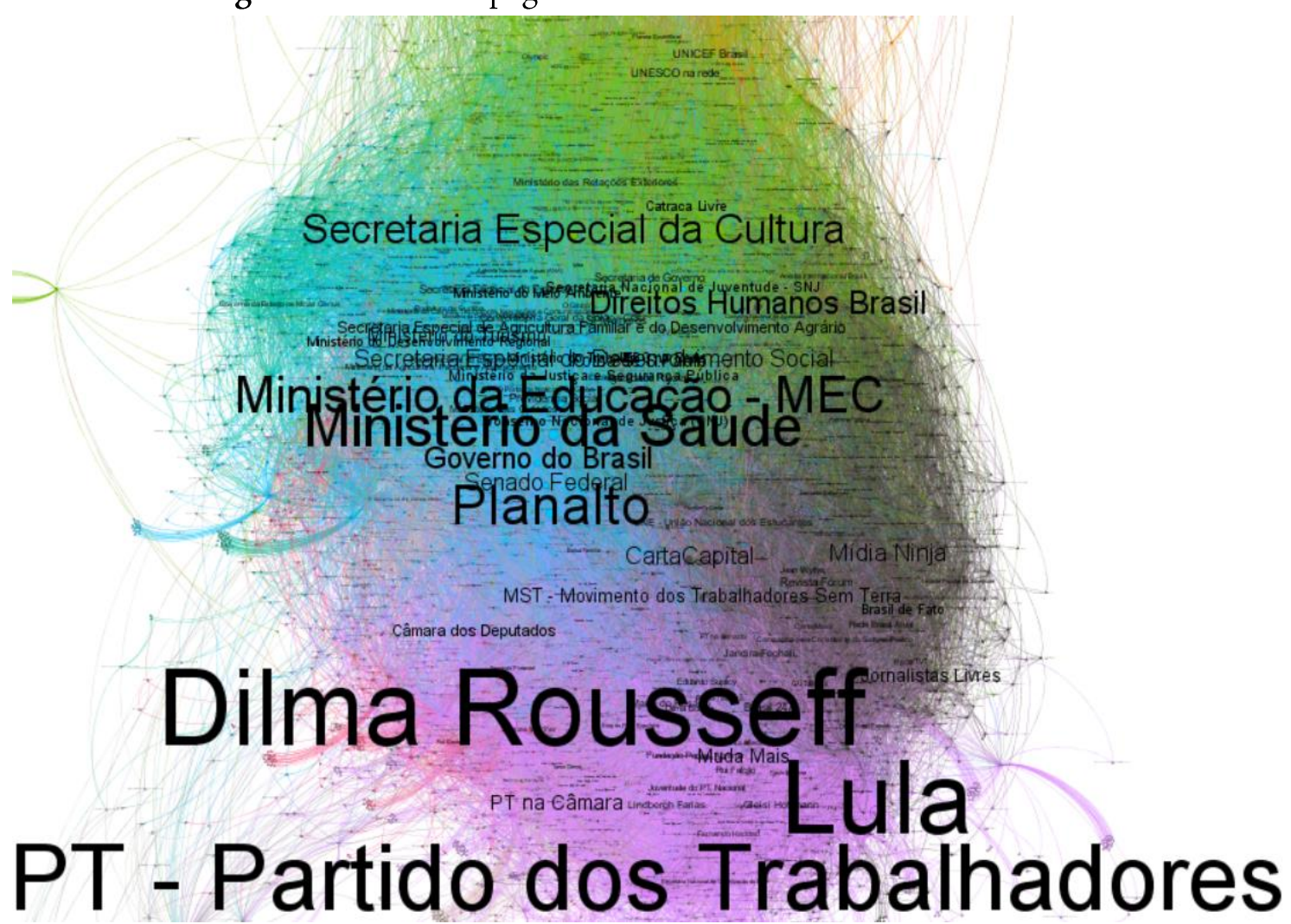

Nota: Os maiores nomes indicam uma maior centralidade (grau de entrada).

Fonte: Elaboração própria.

É possível observar nesse grafo a relevância das páginas de "Dilma”, "Lula” e da própria página institucional "PT - Partido dos Trabalhadores" para a formação da rede do partido no Facebook. Nota-se, pelo tamanho dos nós, que essas três páginas possuem um alto grau de entrada, ficando a página do partido na terceira posição. $\mathrm{O}$ cluster roxo, onde estão localizadas as páginas já citadas, apresenta como principal característica páginas ligadas ao partido e a atores políticos com vínculos no PT. Identifica-se páginas como: "PT na câmara", "Muda Mais", "Juventude do PT Nacional", além de páginas de outros quadros do partido, como: "Lindbergh Farias", "Gleisi Hoffmann" e "Fernando Haddad". Assim, como no caso do PSOL, o cluster onde está presente a página oficial do partido é composto por instituições e quadros ligados à sigla, reforçando a tendência que indicava a literatura (GIBSON e WARD, 2000). 
No entanto, os movimentos sociais vinculados ao PT estão presentes no cluster preto. Neste cluster, observa-se uma forte presença dos movimentos sociais e sindicais, como "MST - Movimento dos Trabalhadores Sem Terra", "UNE - União Nacional dos Estudantes", "Direitos Humanos Brasil", "CUT Brasil”. Esses dados revelam que a ligação histórica do partido com os movimentos sociais e sindicais também é representada nas redes sociais, indo ao encontro do programa partidário e reforçando a identidade do partido também na web (RODRIGUES, BARROS e BERNARDES, 2014). No cluster preto, também são encontrados veículos de imprensa contra-hegemônicos, como "Mídia Ninja", "Carta Capital" e "Jornalistas livres", que abertamente demonstraram apoio a Fernando Haddad nas eleiçóes de 2018 e também se opuseram ao impeachment de Dilma Rousseff, indicando a construção de redes de apoio online pelo partido, como sugere a literatura (GIBSON e WARD, 2000).

O cluster azul é essencialmente formado por instituições de governo, o que reflete os 14 anos que o partido ocupou no Poder Executivo e a sua força institucional. Fazem parte desse cluster as páginas de secretarias de governo e ministérios, como Educação, Saúde e Justiça e Segurança Pública, além de páginas como "Planalto", "Governo do Brasil" e "Senado Federal".

Por fim, o cluster verde também apresenta algumas páginas institucionais, porém com características diferentes, como é o caso da "Secretaria Especial da Cultura", que apresenta vizinhança com páginas relacionadas ao tema. Assim como páginas que fazem ligaçôes com o "Ministério das Relaçóes Exteriores" (presente no cluster azul), como no caso da "UNESCO na Rede" e "UNICEF Brasil". Ainda, é possível registrar que esse último cluster apresenta uma pluralidade de páginas, como é o caso de alguns veículos de imprensa, instituições ligadas à cultura etc. Esse fato também pode ser relacionado com a tentativa de fortalecimento de redes de contato do partido, seguindo o que já era apresentado como tendência na comunicação online (GIBSON e WARD, 2000).

Percebe-se, na rede do PT, a ausência de lideranças menores do partido, mostrando uma concentração de popularidade voltada aos principais nomes da sigla. Nesse mesmo sentido, não se identifica na rede as sedes regionais e municipais, que demonstrariam um poder de capilaridade maior do partido no Facebook, descentralizando a instituição dos principais líderes e regiốes como presumia parte da literatura (GIBSON e WARD, 2000; NORRIS, 2003). 
O MDB é o partido mais antigo dentre os analisados nesta investigação. Historicamente, o MDB tem como marca a luta pela democracia no Brasil, exercendo um papel importante durante à ditadura. Nos últimos 38 anos, o partido teve suas maiores conquistas no cenário político brasileiro. Apesar de não ter ganho uma eleição direta, o partido chegou à Presidência da República em quatro oportunidades 5 . Na última eleição, o $\mathrm{MDB}$ perdeu um número significativo de assentos na câmara, passando de 65, no momento da posse em 2015, para $34 \mathrm{em}$ 2019. Nota-se, no programa do partido, referências ao passado devido ao regime autoritário - o partido destaca a necessidade de organizar as bases da sociedade, fortalecer movimentos sociais e combater privilégios (PMDB, 2014). O MDB defende o compromisso com a democracia liberal, soberania nacional e critica o que chama de "avalanche neoliberal" (PMDB, 2014, p. 13). No entanto, como é possível observar nas conexôes do partido, não existem laços com as bases e movimentos sociais como o programa do partido sugere. O que pode ser observado é algo voltado ao próprio partido político. No grafo (Figura 3), veremos a rede gerada a partir da página do MDB no Facebook.

${ }^{5}$ Chegaram à Presidência da República pelo PMDB/MDB: Tancredo Neves (1985); José Sarney (1985); Itamar Franco (1992); Michel Temer (2016). 
Figura 3 - Rede da página oficial do MDB no Facebook

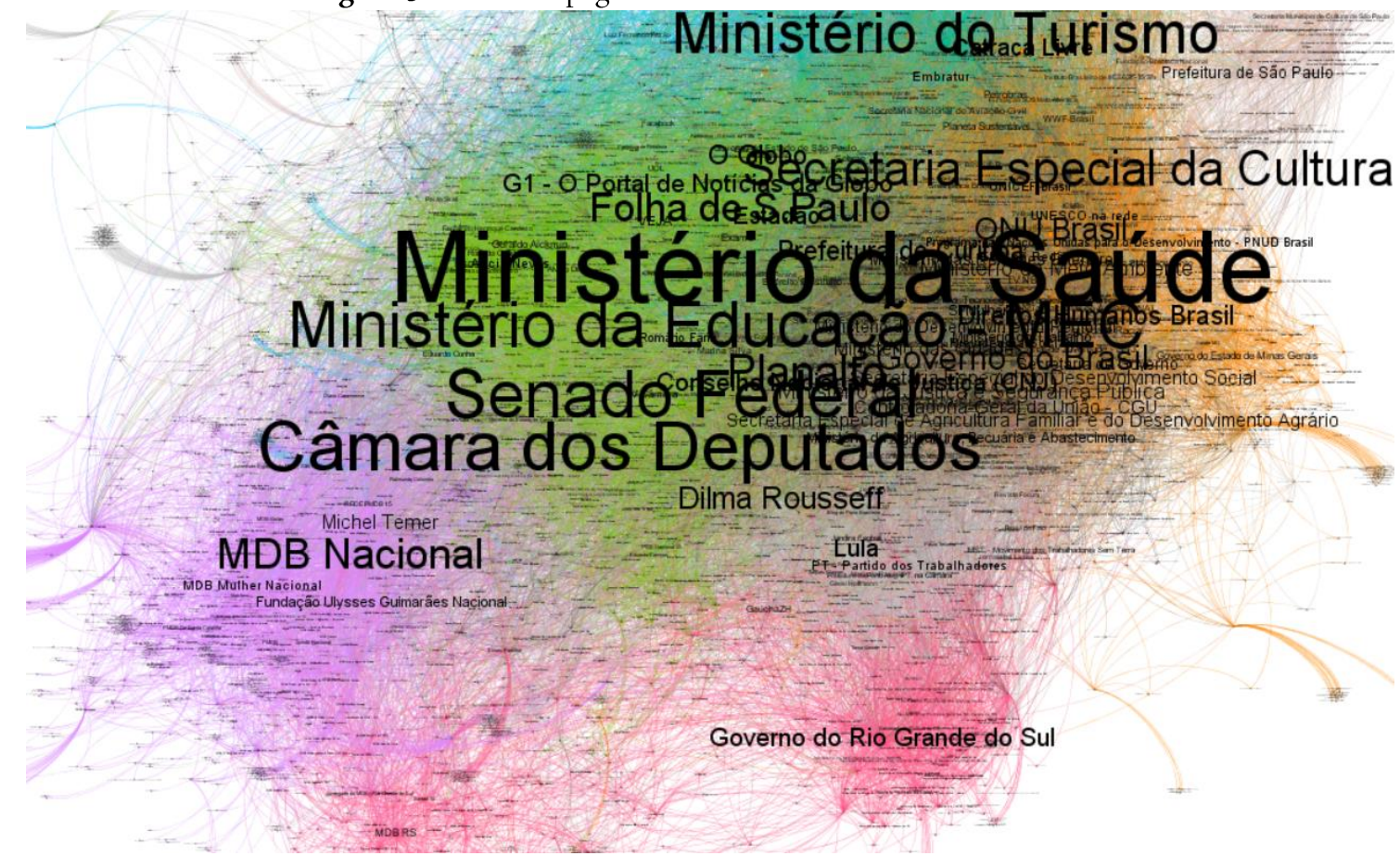

Nota: Os maiores nomes indicam uma maior centralidade (grau de entrada).

Fonte: Elaboração própria.

Começaremos pelo o cluster roxo, onde se localiza o nó da página oficial do MDB. Percebe-se, nesse grupo, que a página do partido tem o nó com maior "relevância", ou, mais especificamente, maior grau de entrada, assumindo uma posição importante dentre o aglomerado de páginas que se conectam, o que pode ser resultado de investimentos nos sites de redes sociais pelo partido nos anos anteriores, assim como a sua representação na Câmara (RODRIGUES, BARROS e BERNARDES, 2014; BRAGA, ROCHA e CARLOMAGNO, 2017). Observa-se nesse cluster, a página "Michel Temer", vice-presidente da chapa de Dilma Rousseff em 2014 e que assumiu o poder após o impeachment em 2016. Também podemos identificar duas páginas ligadas aos movimentos institucionais do MDB, "Fundação Ulysses Guimarães” e "MDB Mulher Nacional”, que demonstram ser dois núcleos importantes dentro do partido. Destacam-se os pequenos grupos que estão aglomerados dentro do cluster, com páginas locais do MDB, como, por exemplo, "MDB Bahia", "MDB Gravatá" ou também páginas de alguns representantes do partido com menor capital eleitoral. Nota-se também segmentações locais, como 
"MDB Mulher AM", "PMDB Mulher de Pará de Minas - Oficial”, "JMDB Paraná" ou "Juventude Democrática Santa Catarina - JMDB SC". Nesse sentido, percebe-se uma maior capilaridade das páginas do $\mathrm{MDB}$ no Facebook, que estão distribuídas em diversas cidades e compóem a rede do MDB Nacional, o que não foi verificado na mesma intensidade nas páginas dos partidos anteriores. Esse dado é encontrado nas investigaçóes anteriores, nas quais se observa uma busca dos partidos por reforçar as instituiçóes, dar visibilidade ao partido, assim como investir em núcleos do partido e a importância a nível local (GIBSON e WARD, 2000; NORRIS, 2003; GIBSON, NIXON e WARD, 2003; RODRIGUES, BARROS e BERNARDES, 2014; BARROS, 2015; BRAGA, ROCHA e CARLOMAGNO, 2017). Neste caso, chama a atenção o número reduzido de quadros do partido com destaque em sua rede basicamente, apenas Michel Temer possui um nó com maior entrada na rede.

O cluster vermelho, vizinho do cluster roxo, apresenta uma característica bem demarcada, pois é referente ao MDB no Rio Grande do Sul. Fazem parte deste cluster páginas institucionais, como "Governo do Rio Grande do Sul" e também "MDB RS", assim como a segmentação "Juventude do MDB - Rio Grande do Sul”, reproduzindo algo semelhante ao cluster da página oficial do partido (RODRIGUES, BARROS e BERNARDES, 2014; BARROS, 2015). É possível explicar essa forte presença do MDB gaúcho na rede devido à importância do partido no estado, onde, de 1985 até 2019, o MDB esteve quatro vezes no comando do Executivo estadual ${ }^{6}$.

Seguindo para o cluster verde, percebe-se que fazem parte do grupo os veículos de imprensa tradicionais, como "Folha de São Paulo", "O Globo", e "G1 Portal de notícias da Globo", mas também há uma forte presença de instituições, reproduzindo algo semelhante ao cluster azul da Figura 2. Observa-se páginas como: "Ministério da Saúde", "Ministério da Educação - MEC", "Câmara dos Deputados" e "Senado Federal”. A vizinhança com essas páginas indica a forte presença da sigla partidária na composição dessas instituiçôes, como é o caso da Câmara dos Deputados, onde o partido consegue resultados eleitorais satisfatórios, estando sempre entre as maiores bancadas da casa ${ }^{7}$, e também por conta da aliança com o PT na história recente, o que resultou na participação do partido no governo federal.

\footnotetext{
${ }^{6}$ Foram governadores do Rio Grande do Sul pelo PMDB/MDB: Pedro Simon (1986), Antônio Brito (1994), Germano Rigotto (2002), José Ivo Sartori (2014).

7 Informação obtida através dos dados apresentados pela Câmara dos Deputados, onde é possível observar a presença do MDB, e anteriormente PMDB, desde 1999 entre as cinco maiores bancadas da Câmara.
} 
Essa mesma aliança é refletida no cluster cinza, que é formado pela rede do PT, forte aliado do MDB durante os governos de Lula e Dilma Rousseff. O que observamos nesse caso é que a rede do $\mathrm{MDB}$ se assemelha à rede do $\mathrm{PT}$, tanto por conta do cluster verde (instituições), mas também pelo cluster laranja, que reproduz o cluster verde da Figura 2 (também composto de instituiçôes diversas). As principais diferenças entre as redes desses partidos estão nas ausências dos veículos de mídia contra-hegemônicos e dos movimentos sociais, que se fazem presentes na rede do PT.

O SDD foi registrado em 2013, sendo esse o partido mais jovem entre os analisados. $\mathrm{O}$ partido divulga a sua história como um partido engajado pela luta trabalhista e pela modernidade política, descrevendo sua principal identidade na relação entre o capital e trabalho, adequando-se à contemporaneidade histórica (SDD, 2014). Ainda nos seus primeiros meses de atuação, o partido recebeu uma representação significativa na Câmara dos Deputados devido a uma forte onda de migração partidária ocorrida em 2013, recebendo quadros de 11 partidos diferentes (DAMIN, 2015), o que indica uma característica "genérica" do partido, que o aproxima de características de "partidos catch-all”, visando maximizar seus ganhos no jogo político (KIRCHHEIMER, 2012). Como a maioria dos partidos políticos brasileiros, o SDD não apresenta posicionamentos e ideologia bem abalizados; no entanto, em seu programa, o partido defende intervenção do Estado na economia (SOLIDARIEDADE, 2014). Na última eleição, o partido foi mais um dos que reduziu o seu número de cadeiras na câmara, passando de 15, em 2015, para $13 \mathrm{em}$ 2019. Na Figura 4, visualizaremos a rede formada a partir da página do SDD no Facebook. 
44 | Nilton Garcia Sainz e Raquel da Cunha Recuero

Figura 4 - Rede da página oficial do SDD no Facebook

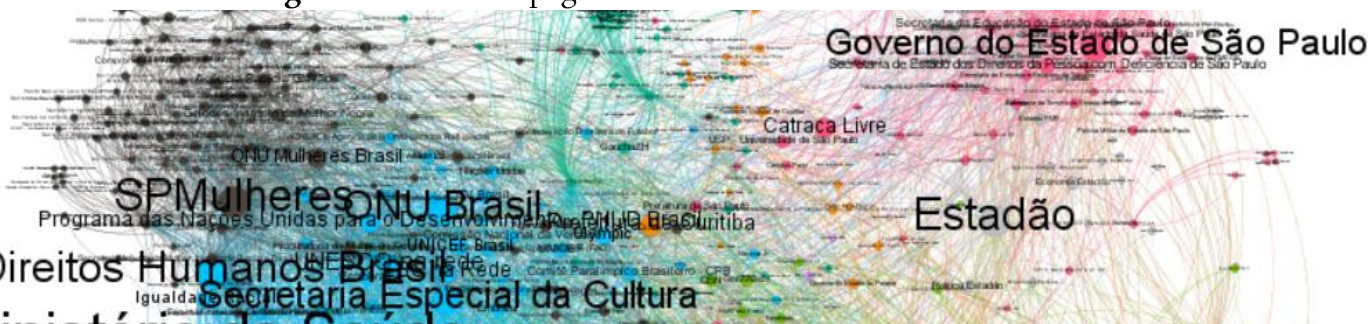

Ministério dasetetider Espoti

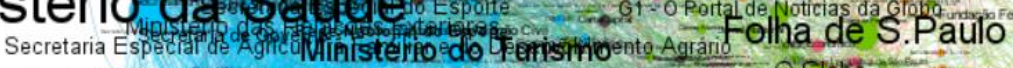

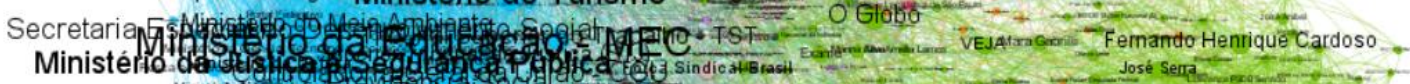

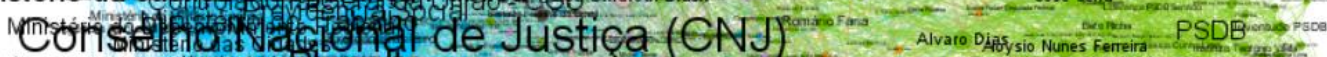

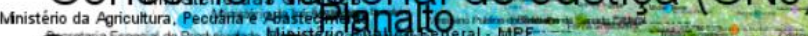

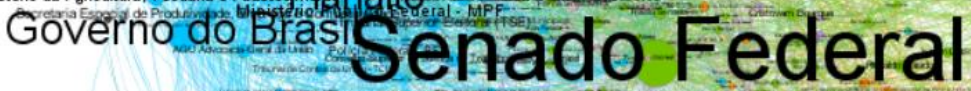

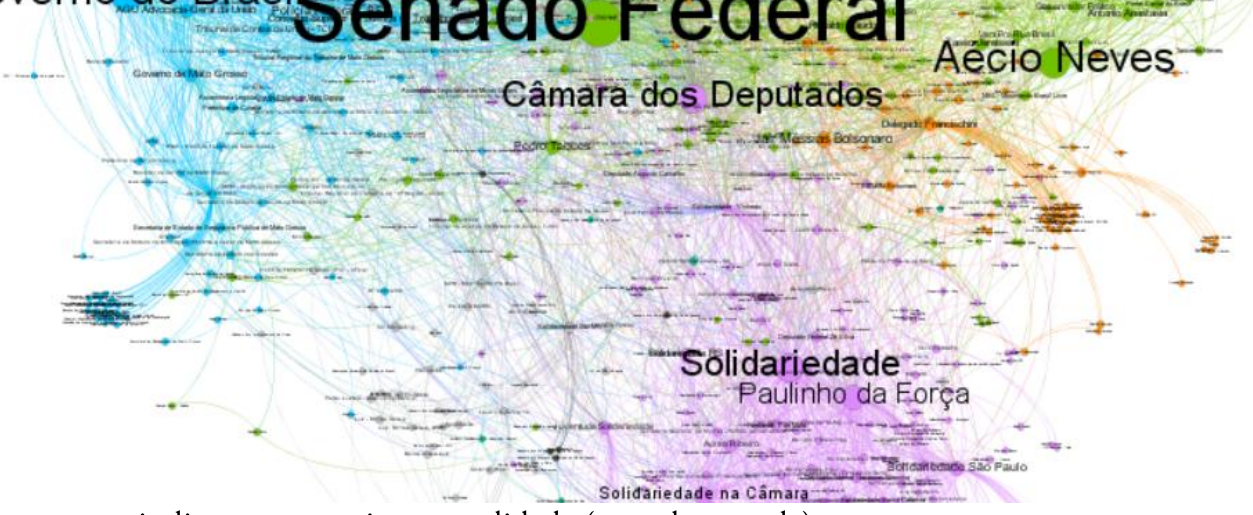

Nota: Os maiores nomes indicam uma maior centralidade (grau de entrada).

Fonte: Elaboração própria.

No cluster roxo, no qual se encontra o nó da página do SDD, percebe-se a relevância da página, sendo este o principal nó em relação ao grau de entrada do cluster. Como é possível observar, este grupo encontra-se mais afastado do centro do grafo, o que indica uma menor vizinhança com o restante da rede. Ou seja, este grupo está próximo dos demais na rede por uma menor quantidade de conexóes do que os outros. O segundo nó mais representativo é "Paulinho da Força", quadro de maior expressão do SDD e que também ocupa a função de presidente nacional do partido. Apesar da ligação de Paulinho da Força com o sindicalismo, isso não fica evidenciado na rede do SDD, que não apresenta conexões com páginas ligadas ao movimento trabalhista, não refletindo o que é descrito no programa do partido. Também se deve destacar que há páginas institucionais que compóem esse grupo, como "Solidariedade na Câmara", "Solidariedade São Paulo", "Solidariedade Rio de 
Janeiro" e outras páginas de diretórios estaduais, indicando a presença organizada do partido nas redes sociais nos estados brasileiros, o que, de certa forma, se verifica na pesquisa de Braga, Rocha e Carlomagno (2017), na qual os partidos com maiores forças eleitorais estavam com maior presença nos sites de redes sociais. Também são identificadas páginas que representam o núcleo de mulheres do partido, indo ao encontro dos apontamentos de pesquisas anteriores (RODRIGUES, BARROS e BERNARDES, 2014; BARROS, 2015), além de outros quadros com menor capital eleitoral. Outro nó que está presente no cluster roxo, porém afastado do nó da página do partido, é "Câmara dos Deputados", o que se explica por conta da força do SDD na casa legislativa.

As páginas que fazem conexão e que estão mais próximas com a página do SDD estão localizadas nos clusters laranja, verde e azul. O cluster laranja é composto por páginas de atores e apoiadores do espectro político à direita. Podem ser identificadas páginas como: "Jair Bolsonaro", "Eduardo Bolsonaro", "Delegado Franschini" e "Olavo de Carvalho". Misturadas a esse grupo laranja e também próximas ao cluster roxo estão as páginas do cluster verde. São identificadas uma variedade de páginas nesse grupo, destacando-se "Aécio Neves", "Senado Federal", "Geraldo Alckmin" e "PSDB". A presença das páginas de Geraldo Alckmin e do PSDB nesse cluster justifica a presença do cluster vermelho, onde está localizado um grupo de páginas referentes ao município de São Paulo, reduto político tucano. Notase que existe uma rede de páginas pró-impeachment no cluster verde que se aproximam do grupo laranja, o que pode ser explicado por conta da mobilização do SDD no impeachment de Dilma Rousseff e demonstra a construção de campanha política do partido, assim como a realização de conexões em busca de fortalecimento do partido nas redes (GIBSON e WARD, 2000; NORRIS, 2001; GIBSON, NIXON e WARD, 2003), o que também pode ajudar na compreensão da presença de diversos representantes políticos à direita na composição dessa rede. Também estão presentes, no cluster verde, páginas de veículos de imprensa tradicionais, como "Veja", "O Globo" e "Folha de São Paulo".

Por fim, o cluster azul reproduz o padrão apresentado pelos demais partidos analisados. Nele estão as páginas institucionais que compõem a rede, o que pode ser justificado tanto pela presença do SDD no congresso brasileiro, por conta de sua força institucional nesse âmbito, mas também pela presença do PSDB na rede, que detém uma maior força política e institucional, já tendo conquistado o cargo de Presidente da República duas vezes, com Fernando Henrique Cardoso. 
46 | Nilton Garcia Sainz e Raquel da Cunha Recuero

O PSL, registrado em 1998, apresentou o maior crescimento eleitoral na última eleição para Câmara dos Deputados, e elegeu o atual Presidente da República, Jair Bolsonaro. O partido, que era considerado pequeno, passou a ocupar a posição de segunda maior bancada na Câmara dos Deputados, com 51 deputados assumindo o posto em 2019, enquanto, no ano de 2015, o PSL tinha apenas um representante na casa. O PSL demarca de forma objetiva seus princípios. Em seu website, o partido descreve suas prioridades em algumas áreas, como segurança pública e violência, proteçáo da propriedade privada, defesa de liberdades individuais e da democracia, revogação do estatuto do desarmamento e "conscientizaçáo a respeito dos males provocados pelo comunismo e socialismo" (PSL, [2019?]). No entanto, diferentemente do site, o programa partidário do PSL (2014) apresenta características menos radicais; nele o partido se coloca como defensor dos direitos humanos, liberdades individuais, defende o Estado como um regulador na economia e ainda diz que "O conservadorismo exagerado e proposital emperra o desenvolvimento" (PSL, 2014, p. 299), divergindo do sentido declarado atualmente no website. O que a rede a seguir apresenta é um PSL alinhado aos princípios descritos em seu website, com proximidades de atores e apoiadores de direita e extrema-direita. Apesar de evidentes contradições, atualmente, o partido político deixa claro seu posicionamento em relação a diversos temas e se posiciona à direita do espectro político brasileiro. $\mathrm{Na}$ Figura 5, atentamos para a rede formada a partir da página do PSL no Facebook. 
Figura 5 - Rede da página oficial do PSL no Facebook

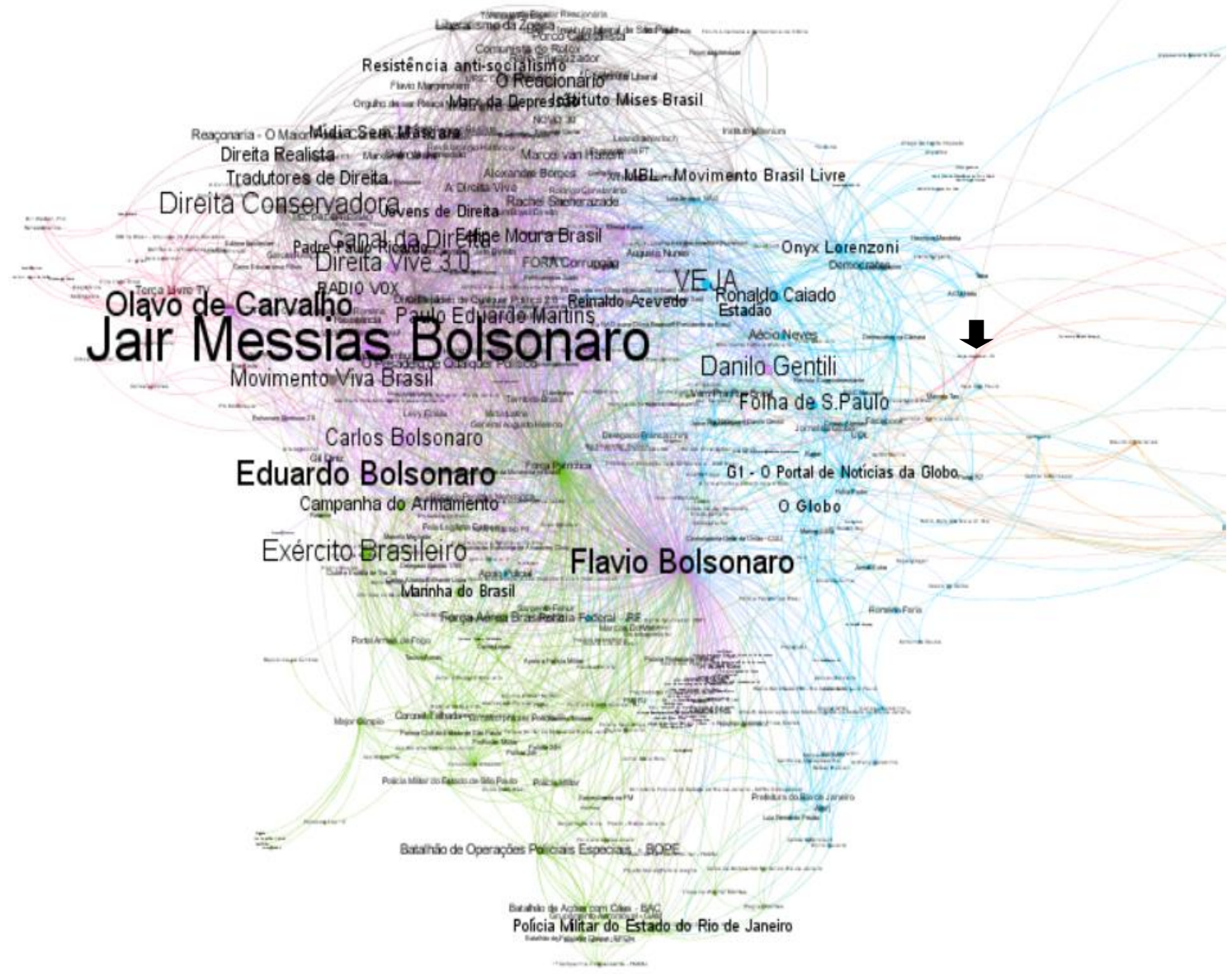

Nota: Os maiores nomes indicam uma maior centralidade (grau de entrada).

Fonte: Elaboração própria.

Diferentemente dos outros casos apresentados até aqui, nesta rede, o nó da página analisada não recebe conexóes, ou seja, sequer possui alguma relevância em algum cluster. A fim de sinalizar onde está localizado o nó do partido, se inseriu na imagem uma seta que aponta para o respectivo nó. Essa informação demonstra a insignificância do partido em sua rede, onde apresenta um grau de entrada igual a zero, significando que a página do PSL apenas realiza conexão em outras páginas, não recebendo conexóes. Além disso, a página realiza um número bem abaixo das demais páginas partidárias analisadas, o que pode ajudar a entender o não recebimento de conexôes. A conexão mais significativa que a página realiza é com "Jair Messias 
Bolsonaro", página oficial do Presidente da República e principal quadro do PSL. Como é possível observar, esse caso se diferencia dos demais, assim como foge daquilo que a literatura da área apontava - que os partidos buscariam construir relações com instituições e fortalecer suas conexões (GIBSON e WARD, 2000). O que se observa é a concentração na conexão com Bolsonaro, ator político que faz com que o partido ganhe notoriedade, dessa forma divulgando e dando visibilidade para a sigla, o que indica uma estratégia diferente desse partido.

O cluster roxo, onde se localiza o nó de Bolsonaro, é composto por uma rede de páginas de direita, onde estáo presentes diversos tipos de atores ligados ao espectro da direita ou extrema-direita. Nota-se que as páginas dos filhos do Presidente estão compondo esse cluster, são elas: "Eduardo Bolsonaro", "Flávio Bolsonaro" e "Carlos Bolsonaro". Destaca-se a aproximação da página de Eduardo Bolsonaro com páginas ligadas ao armamento, bandeira levantada por ele em suas campanhas, e a vizinhança de Flávio Bolsonaro com páginas ligadas ao estado que representa, o Rio de Janeiro. Percebe-se no cluster roxo um número considerável de páginas de influenciadores da direita, como o guru do governo "Olavo de Carvalho", além de "Danilo Gentili", "Reinaldo Azevedo" e "Felipe Moura Brasil". Também se identifica no cluster roxo representantes políticos ligados à direita, como "Paulo Eduardo Martins" e "Marcel Van Hattem". Outra característica desse cluster são as páginas das militâncias de direita, como, por exemplo: "Direita Conservadora", "Canal da Direita" e "Direita Vive 3.0". Além de diversas outras páginas que fazem mençôes ao combate ao comunismo/socialismo e apoio ao conservadorismo e liberalismo econômico. Essas informaçôes reforçam a proximidade existente entre as páginas de direita que atuaram fortemente nas campanhas eleitorais em 2018. Esse fato representa uma característica das campanhas online, demonstrando engajamento da militância que acompanha o ator político (AGGIO e REIS, 2013; MARQUES, 2016), além disso, observa-se a construção de uma identidade promovida pela campanha de Bolsonaro e que também veio a reverberar no partido político (RODRIGUES, BARROS e BERNARDES, 2014).

O cluster verde possui uma característica bem definida. Basicamente, é formado por páginas relacionadas às forças armadas brasileiras, como "Exército Brasileiro", "Marinha do Brasil" e "Força Aérea do Brasil". Além disso, podem ser identificadas páginas de apoio ao armamento da população, como "Campanha do Armamento" e "Portal Armas de Fogo", além de páginas ligadas as polícias militares, como "Polícia Militar do Estado do Rio de Janeiro" e "Batalhão de Operaçóes Policiais Especiais - BOPE”. Nesse cluster, também é possível identificar 
representantes políticos compondo o grupo, como "Major Olímpio"8 e "Coronel Telhada”. O que pode auxiliar na compreensão da presença dessas páginas na rede do PSL é a alta relevância que o partido e seus quadros conferem a esses temas, constituindo-se como uma bandeira presente nas campanhas desses atores políticos ao longo dos últimos anos. Essa informação reforça a estratégia de construção da identidade do partido online e da visibilidade de suas políticas (GIBSON e WARD, 2000; NORRIS, 2003; RODRIGUES, BARROS e BERNARDES, 2014).

Finalmente, o cluster azul apresenta uma diversidade de características nas páginas que o compóe. Nota-se a presença de páginas ligadas aos veículos de imprensa tradicionais, como "VEJA", "Folha de São Paulo" e "Estadão". Também são identificadas páginas de atores políticos atrelados à "política tradicional", como "Onyx Lorenzoni”, "Democratas", “Aécio Neves" e "Ronaldo Caiado".

O maior destaque no caso do PSL, além da irrelevância de sua página para a rede, é a total ausência de páginas ligadas a princípios estabelecidos pelo programa partidário, assim como a inexistência de instituiçôes políticas, indicando um esvaziamento das conexóes entre as páginas de direita e as páginas institucionais. Em suma, o que observamos é uma fragilidade da sigla partidária, que não recebe conexões. Essas ausências reveladas pela rede do partido indicam uma fraca institucionalização na Web, o que fica demonstrado com a inexistência das páginas de diretórios menores na rede, além de não apresentar proximidades dos políticos $\mathrm{da}$ sigla com o nó que representa a página. Assim, observa-se que a rede do PSL é concentrada em Bolsonaro e na rede de direita que surge através da sua presença.

Por fim, analisa-se a rede do PL, sigla partidária que ressurgiu em 2019 com o pedido de alteração da sigla de PR para PL. Em 2015, o partido possuía uma bancada de 34 deputados federais; em 2019, perdeu um assento na casa, reduzindo a bancada para 33 deputados. Ideologicamente, o partido diz possuir uma posição liberal, defendendo a redução do Estado na economia, assim como defende a garantia das liberdades individuais. Porém, o programa do partido apresenta características muito gerais, alcançando todos os temas de maneira muito ampla e com pouca definição (PR, 2014). No entanto, o partido também apresenta fortes características conservadoras e religiosas, sendo responsável por parte considerável da bancada evangélica no país (BOLOGNESI e CODATO, 2018). No grafo (Figura 6), observamos a rede formada a partir da página do PL no Facebook.

\footnotetext{
${ }^{8}$ Também filiado ao PSL, a página do deputado também não realiza conexão com a página do partido.
} 
Figura 6 - Rede da página oficial do PL no Facebook

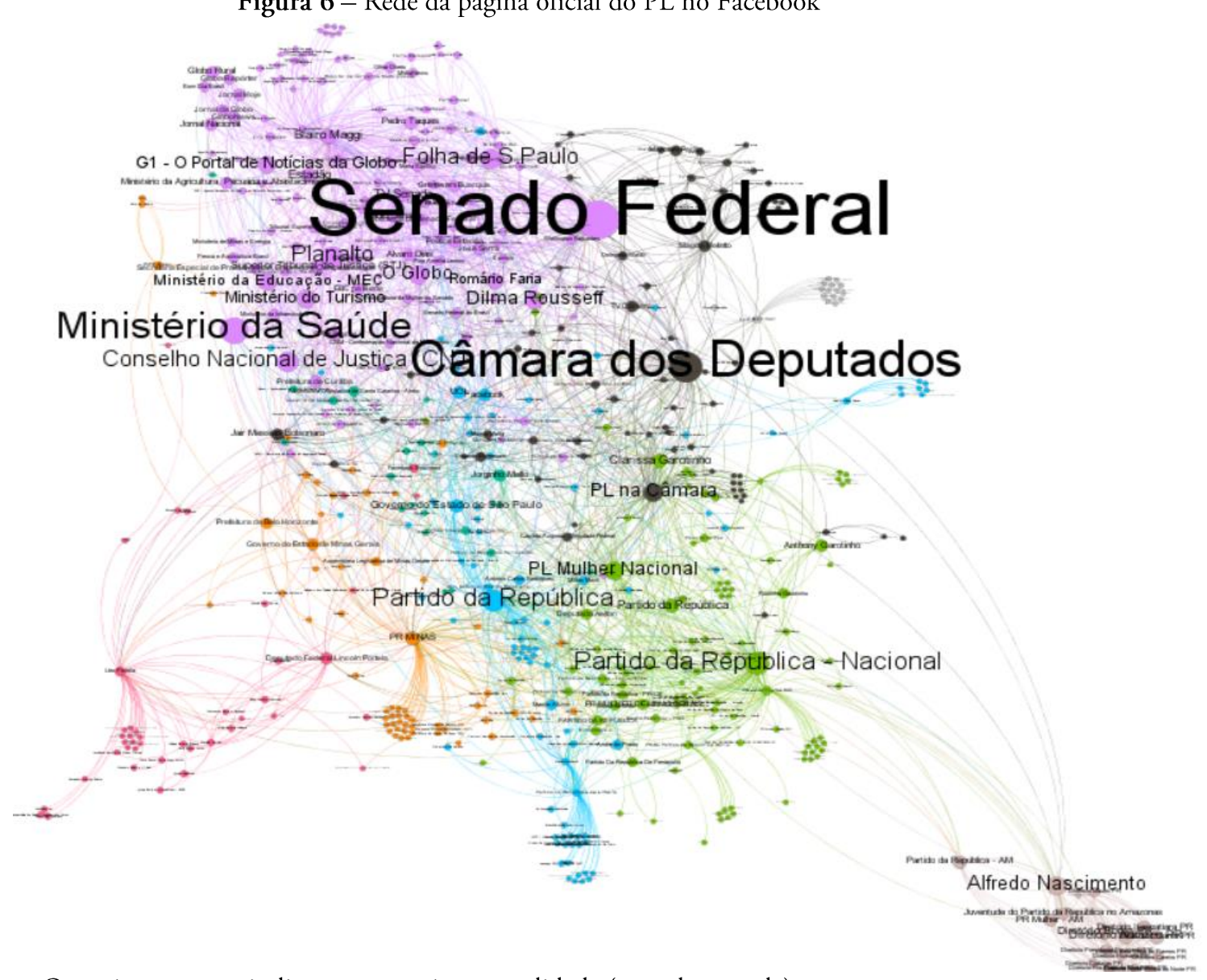

\section{Ministério dâ Saúde}

Nota: Os maiores nomes indicam uma maior centralidade (grau de entrada).

Fonte: Elaboração própria.

Iniciando a análise do grafo pelo cluster verde, onde se localiza o nó do PL, observamos que a página possui uma alta relevância no grupo, sendo o nó com maior grau de entrada, o que indica que recebe um número alto de conexóes. Nota-se nesse cluster a presença de páginas institucionais da sigla, como "PL Mulher Nacional" e "Partido da República". Uma observação importante é que o partido possui grande fragmentação de páginas, isso quer dizer que, mesmo com o website divulgando uma página oficial no Facebook, foram criadas outras muito similares. Percebe-se no cluster a presença de páginas locais, como "PR Mulher de Minas Gerais", o que já foi identificado em outros casos, como do MDB, e que reforça os achados da literatura (BRAGA, ROCHA e CARLOMAGNO, 2017). Identifica-se também a presença de 
páginas de quadros do partido, como é o caso de "Clarissa Garotinho" e "Anthony Garotinho".

Vizinhos do cluster verde, os grupos azul, laranja e bege possuem características muito similares. Como é possível observar no cluster azul, o nó de maior expressão também é "Partido da República", reforçando o que foi mencionado anteriormente em relação ao partido não possuir apenas uma página, o que concentraria todos os seus seguidores. Observa-se, no cluster azul, as páginas de alguns quadros políticos do partido, como "Marcio Alvino" e "André do Prado". No grupo bege, percebe-se a forte presença de páginas de diretórios locais do estado do Amazonas, assim como a presença da página "Alfredo Nascimento", quadro importante do partido no estado. Assim como nos clusters azul e bege, o cluster laranja contém páginas de diretórios locais do PL, neste caso, com maior força em Minas Gerais, reforçando ainda mais a organização institucional do partido nas redes a nível local. Vizinho do cluster laranja, o grupo vermelho apresenta páginas de quadros políticos relevantes do partido no estado de Minas, como "Deputado Federal Lincoln Portela".

Deve-se destacar as instituições que aparecem no grafo, como é o caso da página "Câmaras dos Deputados", mas que são notadas principalmente no maior cluster da rede, o roxo. Assim como na maioria dos casos que foram apresentados anteriormente, páginas de instituições como "Senado Federal", "Ministério da Saúde", "Planalto" e "Conselho Nacional de Justiça - CNJ" se fazem presentes. Observa-se no cluster roxo a página de quadros de outros partidos, como da expresidente "Dilma Rousseff" (que teve o PR como aliado em seus governos), "Romário Faria" e "Blairo Maggi". Identifica-se na extremidade do cluster roxo a presença de alguns veículos de imprensa tradicionais, como "Folha de São Paulo", "G1 - Portal de Notícias da Globo" e "Estadão". No cluster preto, além da página da Câmara dos Deputados, há "PL na Câmara" e "TV Câmara", que reforçam a presença das instituiçóes nesta rede. Nota-se, por fim, a presença de alguns atores políticos de direita, como "Jair Bolsonaro", "Eduardo Bolsonaro", "Olavo de Carvalho" e "Magno Malta". Nesse sentido, há uma característica um tanto genérica das páginas de quadros políticos que estão compondo a rede do PL, e é possível dizer que essa característica é refletida no programa do partido, como citado anteriormente.

A fim de fazer um fechamento em relação aos dados que foram explorados nesta seção do artigo, apresenta-se no Quadro 1 um compilado com as principais características presentes e ausentes nas redes dos partidos políticos analisados. 
Quadro 1 - Características de conexôes das páginas dos partidos políticos no Facebook

\begin{tabular}{|c|c|c|}
\hline Partido & Presenças na rede & Ausências na rede \\
\hline PSOL & $\begin{array}{c}\text { Principais atores políticos; } \\
\text { Instituiçóes do partido; Movimentos } \\
\text { sociais; Imprensa contra- } \\
\text { hegemônica. }\end{array}$ & $\begin{array}{l}\text { Sedes regionais e municipais do } \\
\text { partido; núcleos do partido; atores } \\
\text { políticos de menor capital eleitoral. }\end{array}$ \\
\hline PT & $\begin{array}{c}\text { Principais atores políticos; } \\
\text { instituiçôes do partido; instituiçôes } \\
\text { de governo; núcleos do partido; } \\
\text { movimentos sociais; imprensa } \\
\text { contra-hegemônica. }\end{array}$ & $\begin{array}{l}\text { Sedes regionais e municipais do } \\
\text { partido; atores políticos de menor } \\
\text { capital eleitoral. }\end{array}$ \\
\hline MDB & $\begin{array}{l}\text { Instituiçôes do partido; instituições } \\
\text { de governo; sedes regionais e } \\
\text { municipais; núcleos do partido; } \\
\text { imprensa. }\end{array}$ & $\begin{array}{c}\text { Principais atores políticos; atores } \\
\text { políticos de menor capital eleitoral; } \\
\text { movimentos sociais; } \\
\text { militância/apoiadores. }\end{array}$ \\
\hline SDD & $\begin{array}{c}\text { Instituiçóes do partido; instituiçôes } \\
\text { de governo; sedes regionais e } \\
\text { municipais; núcleos do partido; } \\
\text { atores políticos diversos; atores } \\
\text { políticos de menor capital eleitoral; } \\
\text { imprensa. }\end{array}$ & $\begin{array}{c}\text { Principais atores políticos; } \\
\text { militância/apoiadores; movimentos } \\
\text { sociais; }\end{array}$ \\
\hline PSL & $\begin{array}{c}\text { Predomina um ator político; } \\
\text { militância/apoiadores; pautas de } \\
\text { campanha; atores políticos de } \\
\text { direita. }\end{array}$ & $\begin{array}{l}\text { Instituiçóes do partido; instituiçóes } \\
\text { de governo; principais atores } \\
\text { políticos; sedes regionais e } \\
\text { municipais do partido; núcleos do } \\
\text { partido. } \\
\end{array}$ \\
\hline PL & $\begin{array}{l}\text { Instituiçóes do partido; instituiçóes } \\
\text { de governo; atores políticos diversos; } \\
\text { sedes regionais e municipais; núcleos } \\
\text { do partido; atores políticos de } \\
\text { menor capital eleitoral; atores } \\
\text { políticos diversos. }\end{array}$ & $\begin{array}{c}\text { Militância/apoiadores; movimentos } \\
\text { sociais. }\end{array}$ \\
\hline
\end{tabular}

Fonte: Elaboração própria.

O Quadro 1 ajuda a elucidar aquilo que chamamos de padrôes de conexóes, demonstrando que algumas características se fazem mais presentes entre as páginas partidárias analisadas. Apesar de existir diferenças entre os casos, a característica que mais está presente é a concentração de candidatos nas redes dos partidos, o que pode estar indicando fortes personalismos nas redes. Essa característica ganha destaque principal nos casos do PT e PSL. A rede do PT apresenta os nós de Dilma Rousseff e Lula com alto grau de entrada, inclusive atingindo maiores graus em comparação à própria página da instituição partidária. Já a rede do PSL transparece um 
personalismo ainda mais acentuado. Neste caso, percebe-se o protagonismo da página de Jair Bolsonaro e a baixa relevância do nó correspondente ao PSL, o que indica a fragilidade da sigla em relação ao seu principal ator político na comunicação política online. Também é possível observar essa característica de relevância das páginas dos atores nos demais casos analisados, porém sem demonstrar o mesmo protagonismo desses dois casos citados. Por exemplo, o PSOL apresenta uma série de páginas de candidatos com destaque, mas sem uma concentração especial em um ou dois de maior protagonismo. Já o SDD, MDB e PL apresentam páginas de candidatos com graus de entrada menores, não destacando esses atores políticos na rede partidária.

A segunda característica que merece atenção é a forte presença de instituições políticas e de governos compondo as redes partidárias no Facebook. Como já mencionado, somente no caso PSL não se observa a presença dessas páginas. O que explica a forte presença dessas páginas nas redes partidárias são as relações de institucionalização do partido; assim, o tempo presente no sistema partidário e os cargos ocupados no sistema político levam os partidos a buscar a integração com as novas mídias. Porém, percebe-se que alguns apresentaram características mais específicas dessa institucionalização do partido nas redes sociais online, como é o caso das páginas locais dos partidos. Por fim, vale destacar a relação dos partidos políticos com movimentos sociais e suas bases de apoio, o que está presente nos partidos políticos à esquerda. No entanto, deve-se destacar, na rede do PSL, uma forte presença de apoiadores e militância ligados à campanha de Jair Bolsonaro e que apresentam características específicas de uma militância online.

\section{Considerações finais}

Contribuindo para a compreensão dos padrôes de conexão dos partidos políticos brasileiros no Facebook e como as vizinhanças na rede desses partidos indicam características sobre as instituições partidárias e suas comunicações online, retoma-se a questão que norteou a investigação: quais características possuem as páginas que fazem conexão com os partidos políticos brasileiros no Facebook e o que elas dizem sobre esses partidos e seu caráter institucional na internet?

A pesquisa revela que existem padrões de conexão entre as páginas dos partidos políticos brasileiros, demonstrando características semelhantes entre as instituições partidárias analisadas. Em suma, as páginas dos partidos possuem conexões com páginas ligadas aos seus próprios partidos e a instituiçóes de governo, ou seja, quadros dos partidos, páginas de divulgação e promoção partidária, núcleos e 
sedes locais, além de algumas apresentarem ligações com movimentos sociais e suas bases, indo ao encontro da literatura e daquilo observado em websites partidários, utilizados para fortalecimento de networkings internos e externos dos partidos, assim como para a comunicação com segmentos e núcleos das siglas (GIBSON e WARD, 2000; NORRIS, 2003; GIBSON, NIXON e WARD, 2003; RODRIGUES, BARROS e BERNARDES, 2014; BRAGA, ROCHA e CARLOMAGNO, 2017). Esses dados reforçam o argumento de Braga, França e Nicolás (2009), que apontaram para a existência de um "subsistema partidário virtual", pois se identificou que os partidos realizam conexóes semelhantes, como fica visível no caso de PT e PSOL, e também MDB e PT, indicando que proximidades da política real também podem ser refletidas em conexões online.

No entanto, o caso do PSL foge dos padróes dos partidos que foram analisados. Diferentemente das redes dos demais partidos políticos trazidos na análise, o PSL não apresenta características de um partido institucionalizado. Assim, não são observadas conexões com páginas ligadas as instituiçóes de governo ou até mesmo do próprio partido, o que indica a baixa construção de identidade e estratégia de comunicação política online por parte do partido. O que se configura é o protagonismo da página de Jair Bolsonaro, que, através de suas conexôes, formou a rede visualizada na pesquisa. Sendo assim, identificou-se uma rede de páginas de direita fortemente vinculadas com Jair Bolsonaro e sua rede de apoiadores - o que demonstra a articulação dos atores que apoiaram o candidato a presidente nas eleições de 2018. Com isso, nota-se a busca por fortalecimento de uma identidade política da militância online, assim como a defesa das pautas de campanha de Bolsonaro, algo mencionado pela literatura como estratégia dos atores nas campanhas online (GIBSON e WARD, 2000; NORRIS, 2003; GIBSON, NIXON e WARD, 2003; AGGIO e REIS, 2013; RODRIGUES, BARROS e BERNARDES, 2014; MARQUES, 2016).

Por fim, destacamos exemplos que demonstram a não reprodução da política offline nesta investigação, em que se verifica a força de um partido e ator político que eram de baixa relevância para o cenário nacional e que obtiveram a construção de uma rede de militantes engajados na política online. Mesmo com baixa relevância eleitoral antes do pleito de 2018, a página do PSL possui uma popularidade destacável, com números superiores a partidos fortemente institucionalizados, como o MDB. Entretanto, existe a demonstração de uma baixa institucionalização do PSL no que se refere a páginas institucionais de governo e do próprio partido. Outro destaque é que apenas atores políticos com maiores capitais eleitorais e midiáticos aparecem 
com graus de entrada relevantes nessas redes, o que pode ser um indicativo da dificuldade de atores políticos com menores recursos atingirem crescimentos destacáveis na comunicação online.

Nilton Garcia Sainz é Mestrando em Ciência Política pela Universidade federal de Pelotas. E-mail: sainznilton@gmail.com.

- Raquel da Cunha Recuero é Doutora em Comunicação e Informação pela Universidade Federal do Rio Grande do Sul. Professora do Centro de Letras e Comunicação da Universidade Federal de Pelotas e do Programa de Pós-Graduação em Comunicação Social da Universidade Federal do Rio Grande do Sul. Coordenadora do MIDIARS (UFPel/UFRGS). E-mail: raquel@raquelrecuero.com.

\section{Referências}

AGGIO, Camilo; REIS, Lucas. Campanha eleitoral no Facebook: usos, configuraçóes e o papel atribuído a esse site por três candidatos eleitos nas eleições municipais de 2012. Revista Compolítica, v. 2, n. 3, p. 156-188, 2013.

BARROS, Antônio. Política informacional partidária: como os partidos políticos brasileiros usam a internet para a comunicaçáo com públicos segmentados do eleitorado. Revista Ciberlegenda, n. 32, p. 68-82, 2015.

BOLOGNESI, Bruno; CODATO, Adriano. Sociologia política dos políticos do Brasil: um estudo da competição eleitoral sob o regime da Constituição de 88. In: HOLANDA, Cristina Buarque de; VEIGA, Luciana Fernandes; AMARAL, Oswaldo (Orgs.). A Constituição de 88: trinta anos depois. Curitiba: Editora UFPR, 2018.

BRAGA, Sérgio; FRANÇA, Andressa; NICOLÁS, María. Os partidos políticos brasileiros e a internet: uma avaliação dos websites dos partidos políticos do Brasil. Revista Sociologia e Política, v. 17, n. 34, p. 183-208, 2009. 
BRAGA, Sérgio; ROCHA, Leonardo; CARLOMAGNO, Márcio. Estratégias de comunicação digital dos partidos brasileiros e portugueses: um estudo comparado. Revista Análise Social, n. 223, p. 328359, 2017.

BRASIL é o terceiro país com mais usuários no Facebook. Tecmundo, Curitiba, 27 fev. 2019. Disponível em: <https://www.tecmundo.com.br/redes-sociais/139130-brasil-terceiro-pais-usuariosfacebook.htm>. Acesso em: 27 jul. 2019.

COPPEDGE, Michel. A classification of Latin America political parties. EUA: The Helen Kellogg Institute for International Studies, 1997.

DAMIN, Cláudio. Migração partidária na Câmara dos Deputados em 2013. Revista Em Debate, v. 7 , n. 1, p. 33-49, 2015.

DOS SANTOS, Marcelo; TAVARES, Camila. Análise de redes sociais aplicada à comunicação política: uma proposta metodológica. In: XL ANPOCS - Encontro anual da Associação Nacional de Pós-Graduação e Pesquisa em Ciências Sociais, Caxambu, 2016.

GIBSON, Rachel; WARD, Stephen. A Proposed Methodology for Studying the Function and Effectiveness of Party and Candidate Web Sites. Social Science Computer Review, v. 18, n. 3, p. 301-319, 2000.

GIBSON, Rachel; NIXON, Paul; WARD, Stephan. Parties and the internet: an overview. In: GIBSON, Rachel; NIXON, Paul; WARD, Stephan (Org.). Political parties and the Internet: net gain? Routledge: New York, 2003. p. 11-39.

KIRCHHEIMER, Otto. A transformação dos sistemas partidários da Europa Ocidental. Revista Brasileira de Ciência Política, n. 7, p. 349-385, 2012.

MARQUES, Francisco. Ciberpolítica. Salvador: EDUFBA, 2016.

NORRIS, Pippa. Preaching to the Converted? Pluralism, Participation and Party Websites. Party Politics, v. 9, n. 1, p. 21-45, 2003.

PMDB. PMDB - Partido do Movimento Democrático Brasileiro. In: SENADO FEDERAL (Org.). Partidos políticos brasileiros: programas e diretrizes doutrinárias. Brasília: Senado Federal, 2014. p. $11-44$.

PT. PT - Partido dos Trabalhadores. In: SENADO FEDERAL (Org.). Partidos políticos brasileiros: programas e diretrizes doutrinárias. Brasília: Senado Federal, 2014. p. 69-82.

PR. PR - Partido da República. In: SENADO FEDERAL (Org.). Partidos políticos brasileiros: programas e diretrizes doutrinárias. Brasília: Senado Federal, 2014. p. 327-338.

PSL. Em que acreditamos. PSL, Brasília, [2019?]. Disponível em: <https://psl.org.br/?page_id=27>. Acesso em: 04 ago. 2019.

PSL. PSL - Partido Social Liberal. In: SENADO FEDERAL (Org.). Partidos políticos brasileiros: programas e diretrizes doutrinárias. Brasília: Senado Federal, 2014. p. 297-304.

PSOL. PSOL - Partido Socialismo e Liberdade. In: SENADO FEDERAL (Org.). Partidos políticos brasileiros: programas e diretrizes doutrinárias. Brasília: Senado Federal, 2014. p. 309-326.

RECUERO, Raquel. Métricas de Centralidade e Conversaçóes em Redes Sociais na Internet: Desvelando Estratégias nos Debates Presidenciais de 2014. In: VIII Simpósio Nacional da ABCiber, São Paulo - SP, 2014.

RECUERO, Raquel. Redes sociais na internet. Porto Alegre: Sulina, 2009. 
RODRIGUES, Malena; BARROS, Antônio; BERNARDES, Cristiane. Palanques virtuais: o uso de websites pelos partidos políticos brasileiros. In: $38^{\circ}$ Encontro Anual da ANPOCS, Caxambu - MG, 2014.

SENADO FEDERAL. Partidos políticos brasileiros: programas e diretrizes doutrinárias. Brasília: Senado Federal, 2014.

SDD. SDD - Solidariedade. In: SENADO FEDERAL (Org.). Partidos políticos brasileiros: programas e diretrizes doutrinárias. Brasília: Senado Federal, 2014. p. 355-359.

Texto recebido em 15 de agosto de 2019. Aprovado em 18 de novembro de 2019. 